\title{
Biomass Reburning - Modeling/Engineering Studies
}

\author{
Quarterly Report No. 8 for Period
}

July 1 - September 26, 1999

Prepared by:

Vladimir Zamansky and Chris Lindsey

October 29, 1999

DOE Contract No. DE-FC26-97FT97270--08

Submitted by:

GE Energy and Environmental Research Corporation

18 Mason, Irvine, CA 92618 
$\underline{\text { Disclaimer }}$

This report was prepared as an account of work sponsored by an agency of the United States Government. Neither the United States nor any agency thereof, nor any of their employees, makes any warranty, express or implied, or assumes any legal liability or responsibility for the accuracy, completeness, or usefulness of any information, apparatus, product, or process disclosed, or represents that its use would not infringe privately owned rights. Reference herein to any specific commercial product, process, or service by trade name, trademark, manufacturer, or otherwise does not necessarily constitute or imply its endorsement, recommendation, or favoring by the United States Government or any agency thereof. The views and opinions of authors expressed herein do not necessarily state or reflect those of the United States Government or any agency thereof. 


\begin{abstract}
This project is designed to develop engineering and modeling tools for a family of $\mathrm{NO}_{\mathrm{x}}$ control technologies utilizing biomass as a reburning fuel. During the eighth reporting period (July 1 September 26, 1999), Antares Group Inc, under contract to Niagara Mohawk Power Corporation, evaluated the economic feasibility of biomass reburning options for Dunkirk Station. This report includes summary of the findings; complete information will be submitted in the next Quarterly Report.
\end{abstract}




\section{Table of Contents}

Section $\quad$ Page

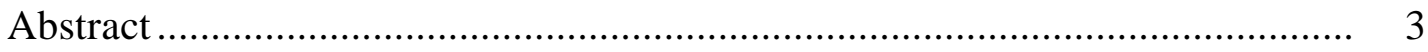

1.0 Introduction ...................................................................................... 5

2.0 Evaluation of Biomass Reburning Options: Summary ............................... 5 


\section{Introduction}

During the eighth reporting period (July 1 - September 26, 1999), Antares Group Inc, under contract to Niagara Mohawk Power Corporation, evaluated the economic feasibility of biomass reburning options for Dunkirk Station. A complete report on the findings of the study will be submitted in the next Quarterly Report.

\section{Evaluation of Biomass Reburning Options: Summary}

The economic feasibility of using micronized biomass as a reburning fuel at a tangentially fired pulverized coal facility like Dunkirk Steam Station was evaluated. Reburning and Advanced Reburning options were considered. Technical and economic performance data are based on information provided by the reburning project team. Specifically, Niagara Mohawk provided data on Dunkirk Station operations and cofiring retrofit costs, GE EER and the Federal Energy Technology Center (FETC) in Pittsburgh provided reburning performance data, and MESA Reduction Engineering and Processing (a developer of biomass processing technologies) provided costs and performance data on micronizing biomass.

Reburning technologies and the market forces that are influencing its application were reviewed. The potential $\mathrm{NO}_{\mathrm{X}}$ reductions for reburning and Advanced Reburning options and pending legislative requirements for lower $\mathrm{NO}_{\mathrm{x}}$ emissions were discussed. Legislative and market incentives that could allow biomass reburning to meet such requirements while increasing plant profit margins were also considered.

The model used in this effort is composed of two main modules: power plant performance and financial performance. The power plant performance module uses inputs based on typical values for utility-scale power plant operations to estimate net plant generation, emissions, and fuel requirements at Dunkirk Station while using biomass reburning. The financial model component is used to calculate the production cost effects of cofiring/reburning based on the plant performance results. Inputs include the delivered cost of fuels, the value of emission credits, tax incentives, green marketing incentives, and capital costs.

Results will assist the Dunkirk Station staff in assessing the potential for biomass reburning to increase the competitiveness of the plant. Preliminary results suggest that biomass reburning can add significant value to plants like Dunkirk and that a host for a demonstration project should be pursued. 